\title{
Synthesis and antimicrobial activity of $\beta$-lactams in dentistry for treatment of root canal infection
}

\author{
M Gowri ${ }^{*}$, R Rajesh², W Sofi ${ }^{1}$, R Raghunathan², V Ganesh ${ }^{1}$ \\ From First International Science Symposium on HIV and Infectious Diseases (HIV SCIENCE 2012) \\ Chennai, India. 20-22 January 2012
}

\section{Background}

The treatment of root canal infection consists of eradicating microbes from the root canal and preventing re infection by root filling. Though the existing intra canal medicaments fight against multidrug resistant microbes in root canal, still re-infections occurs. The objective of this study is to synthesize new $\beta$-lactam compounds and evaluate their antimicrobial activity to treat root canal infections.

\section{Materials and methods}

A series of $\beta$-lactam compounds were synthesized through 1, 3 dipolar cycloaddition reaction and their antimicrobial activity was evaluated against $E$. faecalis, S. aureus, $S$. pneumoniae and C. albicans that are commonly implicated in endodontic failures. The antibacterial activities were assessed in vitro by 1) Agar diffusion test (ADT) 2) MIC by microdilution method 3) Time kill assay 4) Efficacy in ex vivo dentine model 5) Haemolytic assay.

\section{Results}

In this study, 16 compounds were tested and 6 compounds showed activity against $E$. faecalis, S. aureus, $S$. pneumoniae and $C$. albicans. In the time kill assay, the CFUs of E. faecalis were reduced after treatment with the compounds at their MICs. All the 6 compounds showed good antibacterial activity in dentinal tubule model at depth of $200 \mu \mathrm{m}$ and $400 \mu \mathrm{m}$ and the compounds were found to be hemocompatible.

\section{Conclusion}

Overall, our experimental results revealed that $\beta$-lactam compounds exhibited promising antimicrobial activities

\footnotetext{
* Correspondence: microgows@gmail.com

'Department of Human Genetics, Sri Ramachandra University, Porur,

Chennai-600 116, India

Full list of author information is available at the end of the article
}

in dentinal tubule model which can be further explored for the development of potent drugs against microbes involved in endodontic failures.

\section{Author details}

1 Department of Human Genetics, Sri Ramachandra University, Porur, Chennai-600 116, India. '2Department of Organic Chemistry, University of Madras, Guindy Campus, Chennai-600 025, India.

Published: 4 May 2012

doi:10.1186/1471-2334-12-S1-P83

Cite this article as: Gowri et al:: Synthesis and antimicrobial activity of $\beta$-lactams in dentistry for treatment of root canal infection. BMC Infectious Diseases 2012 12(Suppl 1):P83.

\section{Submit your next manuscript to BioMed Central and take full advantage of: \\ - Convenient online submission \\ - Thorough peer review \\ - No space constraints or color figure charges \\ - Immediate publication on acceptance \\ - Inclusion in PubMed, CAS, Scopus and Google Scholar \\ - Research which is freely available for redistribution

C Biomed Central

C 2012 Gowri et al; licensee BioMed Central Ltd. This is an Open Access article distributed under the terms of the Creative Commons Attribution License (http://creativecommons.org/licenses/by/2.0), which permits unrestricted use, distribution, and reproduction in any medium, provided the original work is properly cited. 